\title{
POLLUTION IN THE NORTH SASKATCHEWAN RIVER
}

\section{by Patricia Tones, 15 Bence Crescent, Saskatoon}

With the announcement of a second pulp mill in Saskatchewan it is important to consider the effects of the Prince Albert Pulp Co. Ltd. mill on the water in the North Saskatchewan River.

As a part of a M.Sc. program at the University of Saskatchewan, Saskatoon I sampled the North Saskatchewan River between Prince Albert and Cecil Ferry. My survey sampled the river twice a month from February 1968 to August 1968 (before the mill began production) and from September 1968 to June 1969 (after the mill began production). It gives a useful "before" and "after" comparison and provides useful background information on the effect of a pulp mill on a large Saskatchewan river.

To obtain a measure of pollution I counted coliform bacteria using the membrane filter technique (American Health Association et al. 1965). Since a simple conclusive test for pathogens is not available, coliform bacteria which are present in large numbers in feces are generally accepted as pollution indicators.

The Water Pollution Control Branch (1968) suggested that water containing 10,000 coliform bacteria $/ 100 \mathrm{ml}$ was doubtful and water containing 20,000 coliform bacteria/100 ml was badly polluted (Table 1 ). The maximum limit recommended for waters in the "recreation, fish and wildlife" category was 5,000 coliform bacteria/ $100 \mathrm{ml}$.

My results presented in Table 2 may be compared to criteria suggested by the Saskatchewan Water Resources Commission in Table 1. As an additional check, samples were sent to

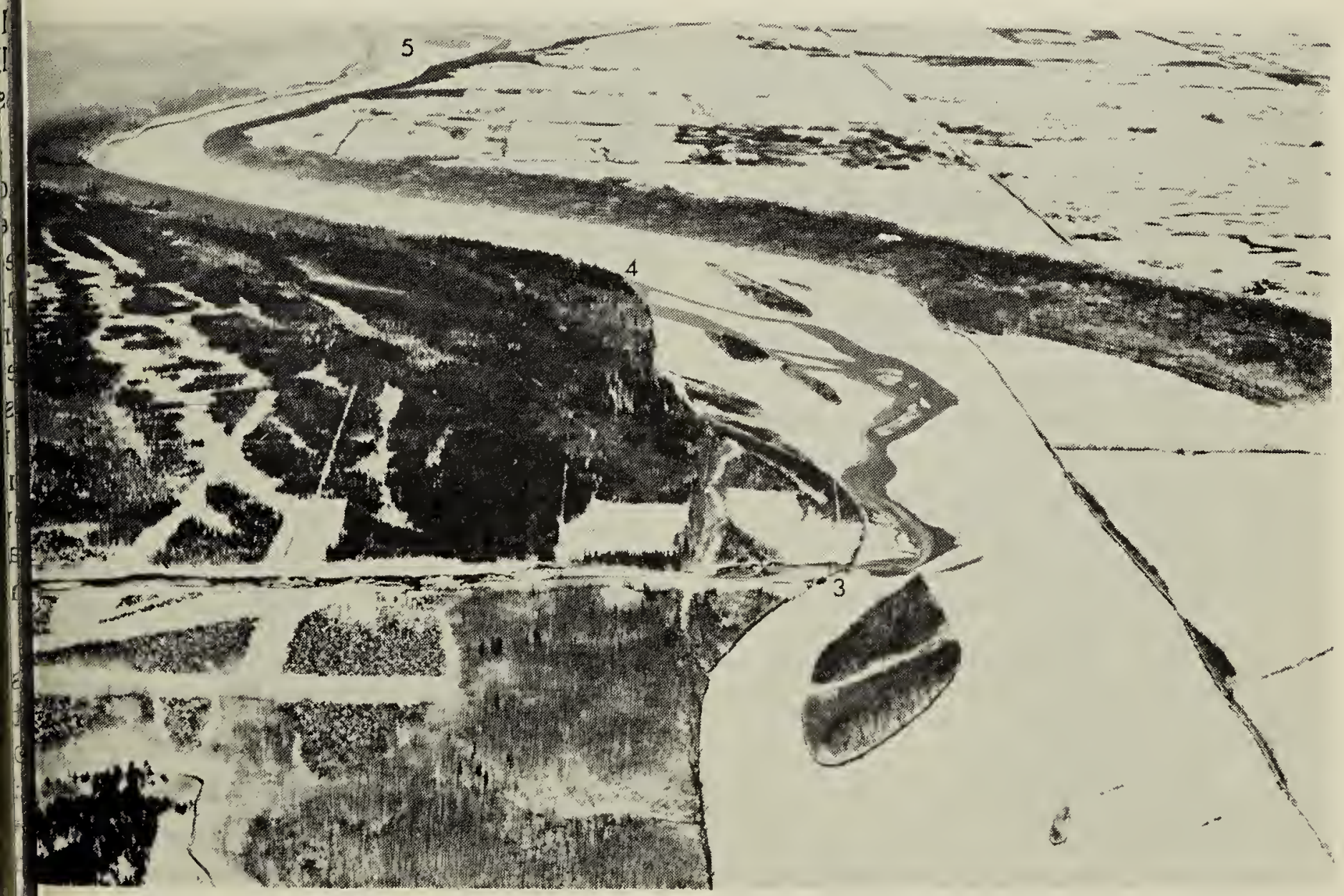

Vinter photo of North Saskatchewan River below Prince Albert showing ulp mill waste entering from left and flowing down river to Cecil Ferry. 
Table 1. Criteria for assessing pollution.

\begin{tabular}{l|c}
\hline $\begin{array}{c}\text { Stream } \\
\text { condition }\end{array}$ & $\begin{array}{c}\text { Coliform } \\
\text { bacteria } / 100 \mathrm{ml}\end{array}$ \\
\hline very clean & 50 \\
clean & 1,000 \\
fairly clean & 5,000 \\
doubtful & 10,000 \\
bad & 20,000 \\
\hline
\end{tabular}

the Public Health Laboratory, Regina, on June 11, 1969. Their results agreed with my high coliform counts in the mill effluent and also verified that the bacteria were of fecal origin. It is obvious from the high coliform counts that the North Saskatchewan River below the Prince Albert Pulp Co. mill is unsafe for any use.

At present the Prince Albert Pulp Co. Ltd. mill has no sewage treatment facilities. Because the sanitary sewers join the industrial sewers above the settling ponds, domestic sewage is mixed with large amounts of warm nutrient-rich wastes.

From the mill approximately 30 million gallons per day of dark brown odoriferous waste containing some foam and small amounts of fibre were discharged into the river. The "clear liquid sewage" described in the Blue Jay, 26:170-171 must not be confused with "colourless" since I was unable to see test fish in a 5-litre glass aquarium containing the waste. The dispersion pipe also mentioned in that article is not in operation, resulting in a concentration of the waste on the north side of the river. The open ditch carrying the waste is shown running horizontally across the centre of the aerial photograph meeting the ice covered river at "3". The waste flows towards the Cecil Ferry, "5", at the top of the picture where the concentration of waste on the north (left) side can be easily seen. The numbers on this photograph are the sampling stations. The average river $\mathrm{pH}$ was 8.5 while the effluent varied erratically from 10.0 to less than 6.8 .

A fish bioassay and a survey of benthic macroinvertebrates were included to evaluate the effect of the mill effluent on river fauna. Sampling of macroinvertebrates in the late spring of 1968 ("before") and 1969 ("after") yielded mainly immature stages of stoneflies, mayflies and chironomids. The results showed severe reduction of both genera and numbers on the north side 1.3 miles below the outfall in 1969. The number of genera had returned to normal at the Cecil Ferry but the total number counted was reduced. In the fish bioassay (Amer. Public Health Ass. et al. 1965), 50\% of rainbow trout parr died in an $18 \%$ solution of the effluent. A similar bioassay with brook stickleback, a less sensitive fish, resulted in no deaths in the 96-hour test period. The effect of the effluent on natural fish populations is unknown but no fish kills occurred during the survey.

The condition of the river, particularly its ability to support life, is dependent on dissolved oxygen which normally approaches saturation in the North Saskatchewan River except during periods of ice cover. Reed (1962)

Table 2. Average concentrations of coliform bacteria in the North Saskatchewan River (bacteria/100 ml).

\begin{tabular}{l|c|c}
\hline \multirow{2}{*}{\multicolumn{1}{c|}{ Location }} & \multicolumn{2}{|c}{ Coliform bacteria } \\
\cline { 2 - 3 } & Jan. '68 to Aug. '68 & Sept. '68 to June '69 \\
\hline above Prince Albert & 71 & 125 \\
pulp mill pump house & 5,570 & 8,356 \\
mill effluent outfall & 978 & $85,800,000$ \\
Cecil Ferry & 989 & $4,520,000$ \\
& & (north side) \\
& & 20,000 \\
& & (south side) \\
\hline
\end{tabular}



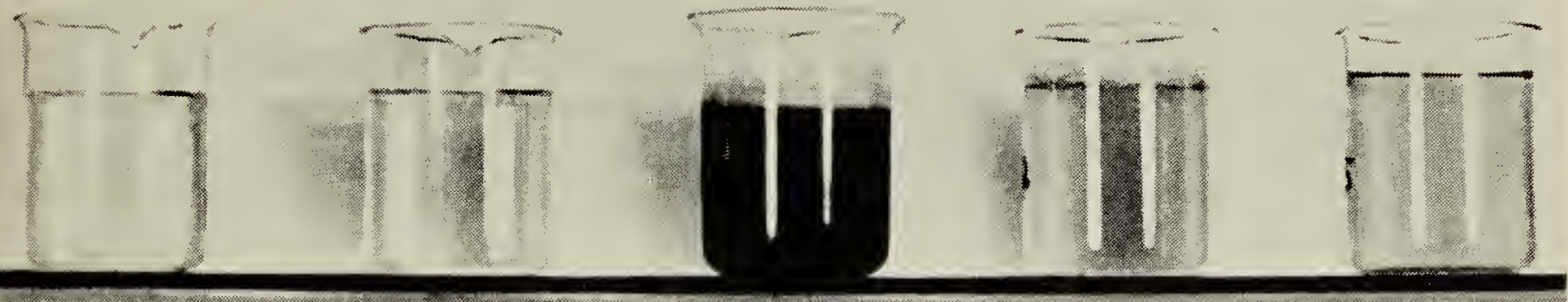

2

3

4

5

SAMELNG STATIOH NUMBEF

APPEARANCE OF WATER SAMPLES TAKEN FROM NORTH SASKATCHEWAN RIVER

reported minimum oxygen levels of less than $1 \mathrm{cc} / \mathrm{l}(1.4 \mathrm{mg} / 1)$ in 1958 attributed to pollution at Edmonton. The minimum I recorded for the river was $4.8 \mathrm{mg} / \mathrm{l}$ in 1968 and $2.8 \mathrm{mg} / \mathrm{l}$ in 1969 , which represented an encouraging improvement. Generally, $5 \mathrm{mg} / \mathrm{l}$ of dissolved oxygen is recommended for varied fish populations with a minimum of $3 \mathrm{mg} / \mathrm{l}$ for short durations. Minimum oxyger levels at the Cecil

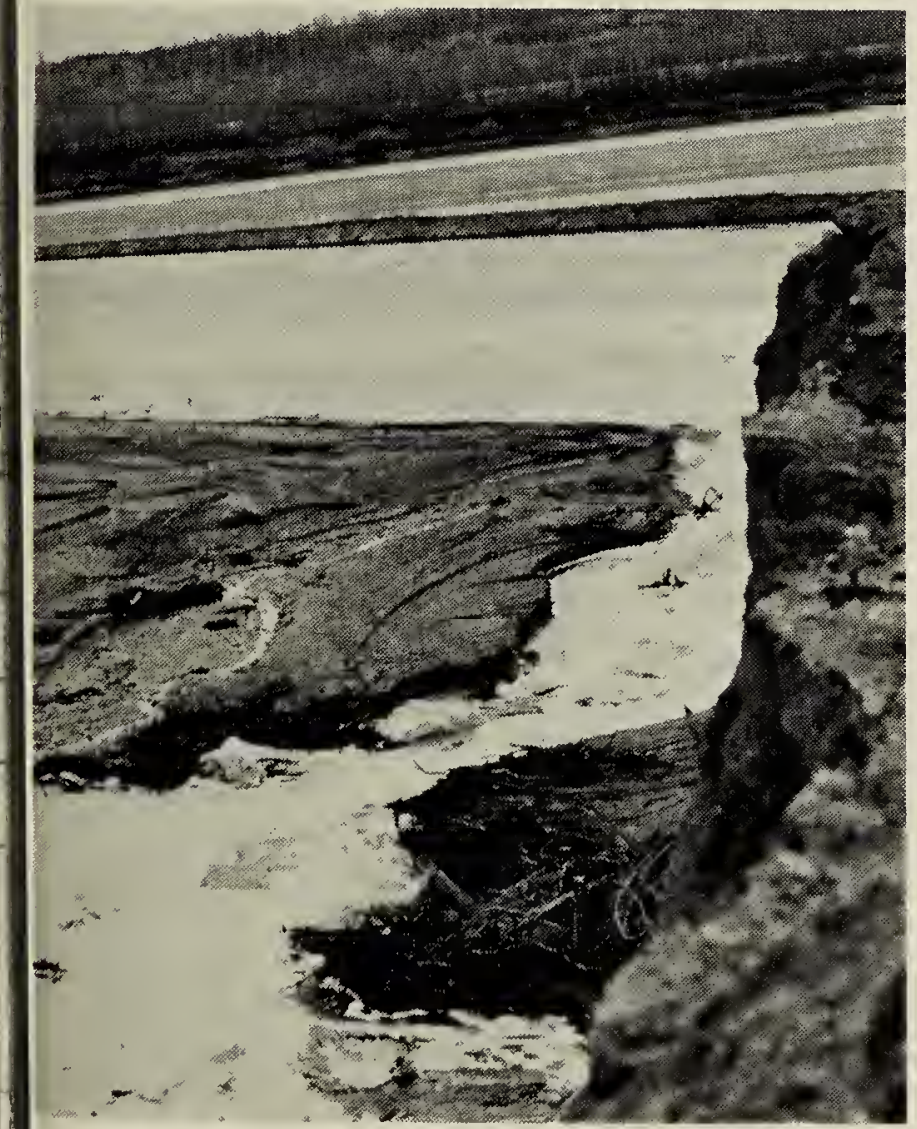

Pulp mill waste entering North Saskatchewan River.
Ferry were the same as those above the mill although little or no oxygen was present in the area immediately below the effluent outfall.

The average biochemical oxygen demand (BOD) of the waste was within the limits of $50,000 \mathrm{lbs}$ day set by the Saskatchewan Water Resources Commission (later reduced to 40,000 lbs/day). These limits are very liberal when compared to the City of Saskatoon which is limited to $30,000 \mathrm{lbs} /$ day with an expected reduction to 20,000 lbs/day.

It is true that the North Saskatchewan River can provide ample water to dilute toxic materials and also, that it has good natural aeration to compensate for the high oxygen demands placed on it (except during winter months). But we, as naturalists, must ask what planning is being done on behalf of the environment at the site of the second mill to be built by the same company. It is more useful to question now than to lament later.

\section{LITERATURE CITED}

Amer. Public Health Ass., Amer. Water Works Ass., and Water Pollution Control Fed. 1965. Standard methods for the examination of water and wastewater. Amer. Public Health Ass. Inc., New York.

Reed, E. B. 1962. Limnology and fisheries of the Saskatchewan River in Saskatchewan. Department of Natural Resources, Regina.

Water Pollution Control Branch. 1968. Water quality criteria. Sask. Water Resources Comm., Kegina. 